\title{
COMMUNICATION STRATEGY IN HANDLING CUSTOMER COMPLAINTS IN PDAM TIRTA PAKUAN BOGOR
}

\author{
Raden Isma Anggraini ${ }^{*}$, Fithriyyah Shalihati*), Muchamad Bachtiar*), and Suhendi*) \\ *) School of Business, IPB University \\ Jl. Pajajaran, Bogor 16151
}

\begin{abstract}
This study aims to 1) identify complaints that arise and do not satisfy customers, and 2) identify communication strategies undertaken by PDAM Tirta Pakuan in handling customer complaints. The study was conducted at PDAM Tirta Pakuan using qualitative descriptive analysis. Researchers surveyed customers and held focus group discussions with the management of PDAM Tirta Pakuan. The method of data analysis is done by using a gap analysis between performance and the interests/expectations of customers for product and service attributes, as well as public relations strategy theory. The results showed that there were four attributes that predominantly received complaints and were not yet satisfying customers, namely the quality of water flow in the dry season, replacement or re-measurement of water meters, compensation for service interruptions, and compensation for settlement of claims for paying bills. Furthermore, there are four communication strategies that are carried out in handling customer complaints based on four aspects, namely factfinding, planning and programming aspects, action and communication aspects, and evaluating aspects. Some things that need attention from the management of PDAM Tirta Pakuan are 1) improving the quality of water supply during the dry season, 2) periodically replacing or repeating water meters, 3) improving the compensation system for customer service interruptions, 4) improving the compensation system related to the problem of settling claims for payment of claims, 5) identifying complaints that have the potential to threaten the image or reputation of the company, 6) maximizing the use of social media in informing work activities that have the potential to cause service disruptions and customer complaints.
\end{abstract}

Keywords: communication strategies, customer complaints, public relations, service disruption, social media

\begin{abstract}
Abstrak: Penelitian ini bertujuan untuk 1) mengidentifikasi keluhan yang timbul dan belum memuaskan pelanggan, dan 2) mengidentifikasi strategi komunikasi yang dilakukan PDAM Tirta Pakuan dalam menangani keluhan pelanggan. Penelitian dilakukan di PDAM Tirta Pakuan dengan menggunakan analisis deskriptif kualitatif. Peneliti melakukan survey terhadap pelanggan serta melaksanakan focus grup discussion dengan manajemen PDAM Tirta Pakuan. Metode analisis data dilakukan dengan menggunakan analisis gap antara kinerja dan kepentingan/ harapan pelanggan atas atribut produk dan pelayanan, serta teori strategi komunikasi humas. Hasil penelitian menunjukkan bahwa terdapat empat atribut yang secara dominan mendapat keluhan dan belum memuaskan pelanggan yaitu kualitas pengaliran air pada musim kemarau, penggantian atau tera ulang meter air, kompensasi atas gangguan pelayanan serta kompensasi atas penyelesaian klaim tagihan pembayaran. Selanjutnya terdapat empat strategi komunikasi yang dilakukan dalam menangani keluhan pelanggan berdasarkan empat yaitu aspek fact-finding, aspek planning and programming, aspek action and communication dan aspek evaluating. Beberapa hal yang perlu mendapat perhatian dari manajemen PDAM Tirta Pakuan adalah 1) meningkatkan kualitas pengaliran air pada musim kemarau, 2) melakukan penggantian atau tera ulang meter air secara berkala, 3) memperbaiki sistem kompensasi atas gangguan pelayanan bagi pelanggan, 4) memperbaiki sistem kompensasi terkait masalah penyelesaian klaim tagihan pembayaran, 5) mengidentifikasi keluhan yang berpotensi mengancam citra atau reputasi perusahaan, 6) memaksimalkan penggunaan media sosial dalam menginformasikan aktivitas pekerjaan yang berpotensi menimbulkan gangguan pelayanan dan munculnya keluhan pelanggan.
\end{abstract}

Kata kunci: gangguan pelayanan, humas, keluhan pelanggan, media sosial, strategi komunikasi

\footnotetext{
${ }^{1}$ Corresponding author:

Email: isma.anggraini@apps.ipb.ac.id
} 


\section{INTRODUCTION}

PDAM Tirta Pakuan Kota Bogor (PDAM Tirta Pakuan) is a Regional-Owned Enterprise owned by the Bogor City Government, which is the only company engaged in the field of clean water services for the people of Bogor City. PDAM Tirta Pakuan has the main task of providing drinking water for the people of Bogor City by following its vision to be the leading company in the field of drinking water services. To realize this vision, PDAM Tirta Pakuan has a mission to provide drinking water services to the community by following existing health standards by considering the affordability of the city and acting as a supporter of regional autonomy and optimally increasing human resources. PDAM Tirta Pakuan was established with the intention of meeting the needs of community drinking water by prioritizing equitable service and health requirements and environmental preservation (Pemkot Bogor, 2011).

In its dynamics, PDAM Tirta Pakuan often receives many complaints from customers regarding the quality, quantity, and continuity of the water that is flowing. All majority customer complaints are submitted through the mass media so that it will significantly impact the positive image of PDAM Tirta Pakuan from the public perspective. On the other hand, PDAM Tirta Pakuan makes customer complaints as a container to overcome must be resolved immediately, it is in line with research conducted by Dinnen and Hassanien (2011) which states that complaints and feedback must be seen as an effort to develop a better relationship between the company and customers as well as efforts to retain customers. Organizational responses to customer complaints will influence post-complaint customer behavior as research conducted by Davidow (2003).

Customer complaints, according to Bell and Luddington (2006), are feedback from customers shown to companies that tend to be negative. Claims are generally perceived as mistakes, problems, stress, frustration, anger, struggle, punishment, demands, compensation, and the like. This feedback can be done in writing or verbally. Consumer complaint behavior occurs when a product or service used by consumers is not by following their wishes (Fanny et al. 2020). Customer dissatisfaction is the response to an evaluation of a discrepancy or confirmed perceived between previous expectations and the actual performance felt after it happened (Tjiptono, 2005). In the event of dissatisfaction, there are several possible actions that customers can take, including 1) customers do not make complaints, but they will no longer use the services of the company concerned; 2) customers make complaints. According to Pardede (2016), customer complaints or complaints are statements and expressions of customer taste for a product or service both verbally and in writing. Claims are generally perceived as mistakes, problems, stress, frustration, anger, conflict, punishment, demands, compensation, and the like. The large number of complaints submitted by customers requires extra attention from company management to always cope and provide better services (Indriyani and Mardiyana, 2016). How well customer complaints are handled by public sector management; this is a significant determinant of quality in public sector services (Brewer, 2007).

There are several ways in which customers submit complaints about service or product dissatisfaction, according to Daryanto and Setyobudi (2014). It is namely: 1) voice response, namely submission of complaints directly to officers who are met; 2) private response, namely the submission of complaints indirectly through third parties such as mass media and NGOs; 3 ) third party response (legal channels), namely submission of complaints through legal channels, class action, compensation and so on.

Some types of customer complaints from PDAM Tirta Pakuan, Bogor City, in general, include: pipe leakage, water that does not flow (dead), turbid water, a meter is jammed, the attitude of officers who are not friendly in serving, and the service of officers is less satisfactory. Therefore we need an appropriate strategy in handling customer complaints that aim to increase customer satisfaction. Proper handling of customer complaints is crucial because PDAM Tirta Pakuan can improve the performance of its public services and be able to maintain customer loyalty and even be able to increase the number of customers for the company's sustainability. Research conducted by Crosby and Stephens (1987) in the service industry suggests that dissatisfaction is one of the factors causing consumer switching, whereas satisfied customers tend to become loyal customers.

Efforts to handle customer complaints have become a strategic concern in many companies, as stated by Cho et al. (2003). This research is needed because every company must have a different communication strategy in maintaining a positive image of the 
company and prioritizing customer satisfaction and loyalty. The role and function of public relations can not be separated from public opinion because one of its functions is to create public opinion that has a goodwill and participation (Herlina, 2015). Communication strategies in dealing with customer complaints are also required to fulfill community rights in accordance with Undang-Undang Republik Indonesia No. 25 Tahun 2009 about Public Services, namely the public is entitled to get a response to complaints submitted and get quality service in accordance with the principles and objectives of the service. Yuliarmi and Riyasa (2007) argue that complaint handling provides an opportunity to turn a dissatisfied customer into a satisfied customer. An effective complaint handling process has begun to be identified, along with determining sources that cause customers to feel dissatisfied and submit complaints. This study aims to 1) identify any complaints that arise and have not satisfied customers of PDAM Tirta Pakuan; 2) identify the communication strategies undertaken by PDAM Tirta Pakuan in handling customer complaints.

\section{METHODS}

The research method used in this study is research using descriptive purposes with qualitative analysis. According to Tajibu (2013), descriptive research is research that aims to explain specific problems or objects in detail. This study focuses on identifying the communication strategy of PDAM Tirta Pakuan in handling customer complaints by referring to four basic principles in identifying the public relations communication strategy process, according to Cuttlip et al. (2009), which includes fact-finding; planning and programming; action and communication; and evaluating. Researchers also use gap analysis in comparing the performance and customer expectations of PDAM Tirta Pakuan product and service attributes.

The study was conducted in Bogor from December 2019 to March 2020. The data and information collected were qualitative and quantitative data. Data obtained through surveys of customers and the type of data used in this study are primary data and secondary data. Respondents in this study were customers and the management of PDAM Tirta Pakuan.

Primary data were obtained from respondents through structured interviews with questionnaires and focus group discussion (FGD) techniques. The sampling technique is done by the respondent clustering system that uses the Cluster Stratified and Systematical Unproportional Sampling (CSUS) technique with the classification of 17 tariff groups that are metric with six zones. The number of customers surveyed was 1996, with 2018 existing respondents as many as 641 people and new respondents in 2019 as many as 1355 people. These customers represent a diversity of customers spread across six drainage zones, 17 tariff groups (industrial, commercial, agency, government, social and household) and seven administrative areas (South Bogor District, East Bogor District, Central Bogor District, North Bogor District, West Bogor District, Tanah Sareal District and part of Bogor Regency). Researchers also conducted FGDs with the management of PDAM Tirta Pakuan as many as four people, including the DirectorGeneral, Public Relations and Customer Service Manager, Assistant Public Relations Manager and Customer Relations Assistant.

Secondary data were obtained from literature study searches relevant to this research through scientific journals and writings sourced from the website and social media owned by PDAM Tirta Pakuan, specifically regarding the handling of customer complaints. The research framework is shown in Figure 1.

\section{RESULT}

\section{General Description}

Customer service is closely related to efforts to provide satisfaction for customers. Customer service is a response to customer problems or complaints (Supriyanto, 2019). Service that satisfies the customer will ultimately have a positive impact on the company because the customer feels the company notices his presence. Referring to the Organizational Structure of PDAM Tirta Pakuan of Bogor City by following Bogor Mayor Regulation Number 54 of 2018, the handling of customer complaints of PDAM Tirta Pakuan is under the control of the Public Relations and Customer Service Manager. The Customer Relations and Services Manager is in charge of Subscription Relations Assistant Managers, Meter Reader Assistant Managers, Assistant Public Relations Managers, and Assistant Marketing Managers. In terms of handling customer complaints, the Subscription Relations Assistant Manager is tasked with providing services to customers that involve interactions with customers to ensure customer satisfaction. 
When company activities occur that disrupt water flowing to customers, PDAM Tirta Pakuan communicates in the form of delivery of information to customers. Various media are used by PDAM Tirta Pakuan so that the information reaches the customer. Figure 2 shows that not all customers have received the notification; the majority of customers feel uninformed at 69 percent.

The most known and easily accessible communication media for PDAM Tirta Pakuan customers is social media, which is 46 percent of customers. Besides, 41 percent of customers access other media, namely word of mouth, information from neighbors, and direct notification from the PDAM, as shown in Figure 3.
The results showed that there were nine product attributes that were assessed for performance by customers, as listed in Table 1. Table 1 shows the actual conditions and PDAM customer expectations for the product's performance in the future. Of the nine attributes, almost all attributes have lower performance when compared to customer expectations, especially in terms of water quality and continuity (attributes P3, P4, P5, and P6). In general, all product attributes need to be improved by PDAM Tirta Pakuan so that its performance approaches customer expectations, and the magnitude of the gap or gap between expectations and actual conditions can be minimized.

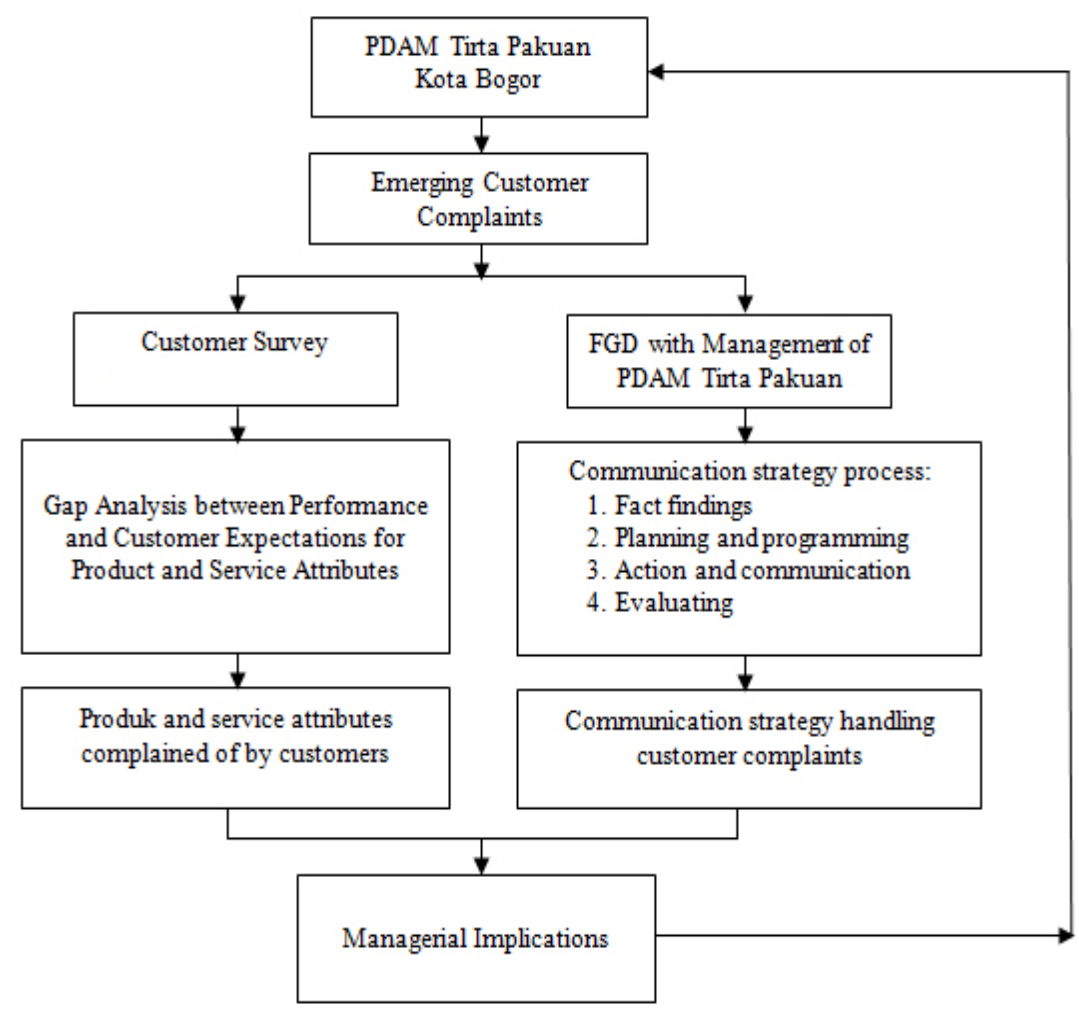

Figure 1. The research framework

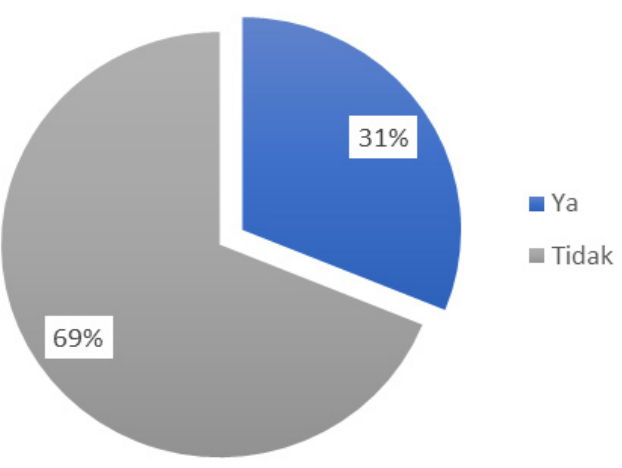

Figure 2. Respondents' perceptions about the provision of information on PDAM Tirta Pakuan

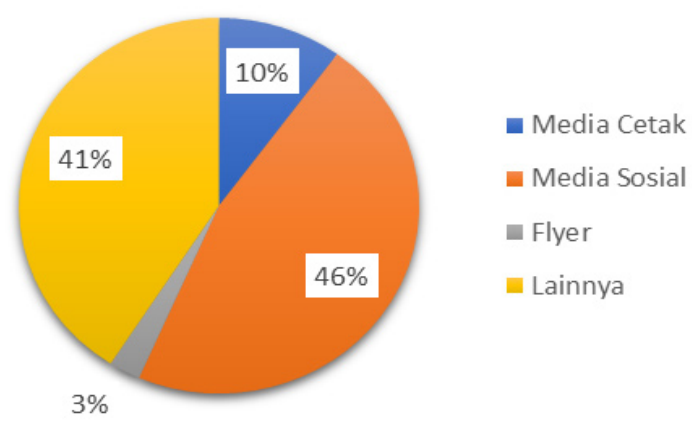

Figure 3. Respondents' perception about the information media on PDAM Tirta Pakuan 
In terms of service attributes, the results of the study showed that eleven service attributes were assessed for performance by customers, as listed in Table 2 . Table 2 shows the actual conditions and expectations of PDAM customers for the performance of service attributes in the future. Of the eleven attributes, the attributes J8 (compensation for service interruptions) and J9 (compensation for settlement of claims for payment of claims) are attributes that must be further improved compared to the other attributes. However, in general, the overall attributes need to be enhanced by PDAM Tirta Pakuan so that its performance approaches customer expectations and the magnitude of the gap or gap between expectations and actual conditions can be minimized.
The performance of PDAM Tirta Pakuan services, in general, has not been able to meet the expectations of all customers. Based on the research results, there are still many customer complaints that indicate PDAM Tirta Pakuan is demanded to improve service performance. Based on the results of the study, the attributes that have not met customer satisfaction and complained of by customers are: Quality of drainage in the dry season (P1); Replacement or re-calibration of water meter replacement (P8); Compensation for service interruptions (J8); Compensation for settlement of claims for payment bills (J9).

Table 1. Gap analysis of product performance attributes of PDAM Tirta Pakuan

\begin{tabular}{lcccc}
\hline Type of service & Attributes & Actual & Expections & Gap \\
\hline Quality of water flow in the dry season & P1 & 2.90 & 3.33 & 0.43 \\
Quality of flowing water in the rainy season & P2 & 3.02 & 3.38 & 0.36 \\
Continuity of water flow & P3 & 2.98 & 3.40 & 0.42 \\
Water quality: bacteria and taste free guarantee & P4 & 2.98 & 3.40 & 0.42 \\
Water qualitu: clarity & P5 & 2.98 & 3.40 & 0.42 \\
Water quality: smell & P6 & 2.98 & 3.40 & 0.42 \\
Water quality: sediment & P7 & 3.33 & 3.32 & -0.01 \\
Water quality: Replacement/recycling of water meter & P8 & 2.83 & 3.19 & 0.36 \\
Product: ZAMP (Zona Air Minum Prima) \& KASM (Keran Air & P9 & 2.66 & 3.11 & 0.45 \\
Siap Minum) & & & & 3.28 \\
\hline Total & Average & 26.66 & 29.94 & 3.33 \\
\hline
\end{tabular}

Tabel 2. Gap analysis of service performance attributes of PDAM Tirta Pakuan

\begin{tabular}{|c|c|c|c|c|}
\hline Type of service & Attributes & Actual & Expectations & Gap \\
\hline Administrative services & $\mathrm{J} 1$ & 3.02 & 3.28 & 0.26 \\
\hline Bill payment & $\mathrm{J} 2$ & 3.11 & 3.31 & 0.20 \\
\hline Completion of complaints & $\mathrm{J} 3$ & 3.01 & 3.23 & 0.22 \\
\hline Justice getting service & $\mathrm{J} 4$ & 3.02 & 3.25 & 0.23 \\
\hline Capability of customer service officers & $\mathrm{J} 5$ & 3.06 & 3.29 & 0.23 \\
\hline Capability of PDAM call centers officers & $\mathrm{J} 6$ & 3.09 & 3.47 & 0.38 \\
\hline $\begin{array}{l}\text { The capability of the social media admin officer and the PDAM } \\
\text { website }\end{array}$ & $\mathrm{J} 7$ & 3.10 & 3.45 & 0.35 \\
\hline Compensation for service interruptions & $\mathrm{J} 8$ & 2.37 & 3.25 & 0.88 \\
\hline Compensation for settlemnet of claims for payments bills & J9 & 2.64 & 3.16 & 0.52 \\
\hline Settlements of disputes with customers & $\mathrm{J} 10$ & 3.12 & 3.30 & 0.18 \\
\hline Service interruption information & $\mathrm{J} 11$ & 2.96 & 3.29 & 0.33 \\
\hline Total & 32.5 & 36.28 & 3.52 & \\
\hline Average & 2.95 & 3.30 & 0.29 & \\
\hline
\end{tabular}




\section{Communication Strategy of PDAM Tirta Pakuan}

\section{Fact-Finding}

Based on research through FGD with PDAM management, to identify complaints from PDAM customers, data, or facts are collected first. The collection of data or facts is carried out using direct and indirect communication media. Direct communication is done face-to-face at the PDAM Tirta Pakuan Office, media gathering activities, and customer gathering activities. Indirect communication that includes call center services, SMS centers, social media, print media. Based on the fact-finding obtained problems that occur related to the products and services of PDAM Tirta Pakuan. Referring to the survey, there are four attributes that customers complain about, namely: the quality of water flow in the dry season, replacement or re-replacement of water meters, compensation for service interruptions, and compensation for settling claims for paying bills.

Furthermore, in the process of handling customer complaints, the customer complaint service staff is tasked with receiving and delivering the types of complaints submitted by customers to the relevant parts and their respective resolutions. Not only the response, but the company also needs the advice to understand customer desires so that customers will be fulfilled expectations. Organizational responses to customer complaints will be able to increase customer profitability, where the ability of organizations that respond quickly and satisfy customers will be able to increase overall company profits in line with research conducted by Fierro et al. (2015).

\section{Planning and Programming}

Based on the results of the FGD with the management of PDAM Tirta Pakuan related to customer complaints, the next step is to plan and create a program that is by following the complaints raised by the customer. For complaints submitted directly, PDAM Tirta Pakuan deals with:

1. Listen to customer complaints. Customer service staff give full attention to customers who are sending their complaints so that officers understand the root of the problem and can find a right solution.

2. Letting customers express their complaints. Customer service staff allows customers to talk without interrupting.
3. Apologize for the inconvenience that the customer feels. The customer service staff apologized for the mistakes and difficulties caused by PDAM Tirta Pakuan

4. Convincing customers that team can overcome problems and assuring customers that this will not be repeated.

5. Saying thank you. Customer service staff thank customers who have complained about issues and customer inconveniences. Based on the customer's report, the PDAM can improve services to customers so that the problem will not be repeated later.

Regarding the program in handling customer complaints, PDAM Tirta Pakuan has made the following programs: Open PDAM Tirta Pakuan service outlets at Mall Pelayanan Publik (MPP) Kota Bogor; Customer outreach programs; Training programs for employees; Customer complaint information system development program; Customer satisfaction survey program.

\section{Action and Communication}

In realizing and carrying out the plans and programs that have been made, PDAM Tirta Pakuan carries out various actions and communications to customers. PDAM Tirta Pakuan synergizes with the Bogor City Government in opening the PDAM Tirta Pakuan service outlets in the Mall Pelayanan Publik (MPP), Kota Bogor. The services provided by PDAM Tirta Pakuan at MPP outlets include handling customer complaints, new installations, payment of water bills, changing the customer's name, moving meters, and so on. PDAM Tirta Pakuan customer service staff on duty at MPP outlets provides various information services that are needed by the community.

PDAM Tirta Pakuan also runs customer outreach programs that aim to inform in detail about the water treatment process from upstream to the hands of consumers. For example, complaints about the dark color of the water and the small flow of water every morning and night. To answer this question, PDAM Tirta Pakuan can provide a presentation to explain the causes of conditions experienced by customers. This socialization activity is carried out in the form of customer gatherings or media gatherings. In connection with this program, PDAM Tirta Pakuan may re-elect Water Ambassador elections which have been held some time before, so that the activities of the PDAM program's socialization and education and handling 
of water resources can run in a format that is more interesting and easy to remember by customers.

PDAM Tirta Pakuan builds effective communication as an essentials role in improving the quality of service for customers and generating a positive image for the company. PDAM Tirta Pakuan sets high standards in the service of call centers 24 to customers. Officers who are proven capable of carrying out their duties will be given exclusive rewards or rewards. In contrast, officers who are less proficient or negligent in handling consumer complaints are subject to punishments or sanctions in force. Call center operators are demanded to be more professional in carrying out their duties in serving various information such as information on flow problems, new installation services, and billing information, as well as being better at handling customer complaints. This condition requires the call center staff to have comprehensive security for all types of products the company has and knowledge of the source of raw water from the PDAM. Call center staff can be given the opportunity to make visits to allnatural water sources so that when call center officers face complaints or questions from customers, they can answer questions and criticisms faced by customers quickly and directly. With the ability of professional and reliable call center officers, customer complaints will be faster to be handled. Call center staff are also required to be able to manage emotions positively to build effective communication with customers.

PDAM Tirta Pakuan provides training for human resources to improve their expertise in utilizing social media and call centers. PDAM Tirta Pakuan provides training for human resources to enhance their abilities and knowledge in using social media. The training aims to provide human resources in interacting and handling customer complaints on social media. Training that can be given includes service excellence training or excellent communication skills training. Customers of PDAM Tirta Pakuan prefer the current use of social media by following the results of a survey of customers stating that 46 percent of customers have used social media in filing complaints. The most popular choice for social media right now is Instagram, and it is noted that the number of followers in the PDAM Tirta Pakuan Instagram account is 6,875 people. In today's digital era, PDAMs are required to understand and master a variety of skills in providing excellent service and handling customer complaints. HR is also needed to be able to learn ethics in communicating both ethics directly and ethically through social media and both verbal and nonverbal communication.

PDAM Tirta Pakuan has developed a customer complaint information system that can help improve customer service with a fast response and documentary evidence stored in a database. At present, the PDAM already has an Android-based SIMOTIP (Sistem Informasi Mobile Tirta Pakuan) application to facilitate customers in submitting their complaints and access various information related to PDAM Tirta Pakuan. However, it is expected that in the future, PDAMs can provide early warning information regarding planned activities to be carried out by companies that have the potential to cause water disruption to customers. The development of this information system is expected to help the PDAM Tirta Pakuan call center or customer service operations in improving quality and accelerating service to customers, as has been stated by Hasugian and Idrus (2015) in his research.

PDAM Tirta Pakuan carries out a Customer Satisfaction Survey (CSS) routinely every year by involving third parties. To improve the performance of its products and services, PDAM Tirta Pakuan always needs advice and criticism from its customers, specifically related to customer satisfaction. Customer complaint handling is a system of handling customer complaints in an organized way to respond, record reports, and use complaints to improve service to customers.

\section{Evaluating}

Evaluations of the various program implementations are evaluated to see the extent of the effectiveness of its implementation and what programs have the most significant impacts. Based on the research results, it is known that the communication media that are currently the most known and easily accessed by customers of PDAM Tirta Pakuan are social media, which is as much as 46 percent of customers. Therefore, the handling of customer complaints can be maximized on this media, especially the Instagram account @ perumdatirtapakuan, which has 6,875 followers and Whatsapp media. Through these two social media, PDAM Tirta Pakuan can actively inform the service disruption caused by the work being done. This is consistent with research conducted by Gunarathne et al. (2017), who found that customers who submit 
complaints on online social media tend to feel more satisfied because they feel more personally served and more quickly responded.

\section{Managerial Implication}

Some things that need attention from the management of PDAM Tirta Pakuan are as follows: Improve the quality of water drainage in the dry season; Perform regular replacement or repetition of the water meter; Improve the compensation system for service interruptions for customers; Improve the compensation system related to the problem of payment claim claims; Identifying complaints that have the potential to threaten the company's image or reputation. In this case, PDAM Tirta Pakuan is demanded to be always responsive, responsive, and solutive in handling customer complaints. This is by following research conducted by Pratama (2017), where the posting of complaints on social media can be read by the public so that it has the potential to reduce the company's positive image; Maximizing the use of Instagram and WhatsApp social media in informing work activities that have the potential to cause service disruptions and customer complaints.

\section{CONCLUSIONS AND RECOMMENDATIONS}

\section{Conclusions}

Based on the results of the study, it was concluded that complaints arising from and not yet satisfying customers of PDAM Tirta Pakuan include four attributes, namely the quality of water flow in the dry season, replacement or re-replacement of water meter replacement, compensation for service interruptions and compensation for settlement of claims for paying bills. Furthermore, the communication strategy in handling customer complaints from PDAM Tirta Pakuan is divided into four aspects:

First, in the fact-finding element, based on research through FGD with PDAM management, data or fact collection is carried out using direct and indirect communication media. Direct communication is done face-to-face at the PDAM Tirta Pakuan Office, media gathering activities, and customer gathering activities. Indirect communication that includes call center services, SMS centers, social media, print media. Based on the fact-finding obtained problems that occur related to the products and services of PDAM Tirta Pakuan. Referring to the survey, there are four attributes that customers complain about, namely: the quality of water flow in the dry season, replacement or re-replacement of water meters, compensation for service interruptions, and compensation for settling claims for paying bills.

Second, in the aspect of planning and programming, there are several programs in dealing with customer complaints, namely: opening a service outlet of PDAM Tirta Pakuan at the Mall Pelayanan Publik (MPP) Kota Bogor, socialization and education programs for customers, training programs for employees, complaints information system development program customers, and customer satisfaction survey programs.

Third, in the aspect of action and communication, in realizing and carrying out plans and programs that have been made, PDAM Tirta Pakuan carries out a variety of actions and communications to customers, namely: 1) Synergy with the Bogor City Government in opening PDAM Tirta Pakuan service outlets at the Mall Pelayanan Publik (MPP) Kota Bogor, 2) Carry out socialization and education programs to customers that aim to inform in detail about the water treatment process from upstream to the hands of consumers, 3) Establish effective communication as an important role in improving the quality of service for customers and produce a positive image for the company, 4) Provide training for human resources to enhance their expertise in utilizing social media and call centers, 5) Develop customer complaints information systems that can help improve customer service with fast responses and documentary evidence stored in databases, 6) Implement the regular Customer Satisfaction Survey (CSS) every year involving third parties.

Fourth, on the evaluating aspect, based on the research results, it is known that the communication media that are currently the most known and easily accessed by customers of PDAM Tirta Pakuan are social media, which is as much as 46 percent of customers. Therefore, the handling of customer complaints can be maximized in this media, especially the Instagram account @ perumdatirtapakuan and Whatsapp media. Through this account, PDAM Tirta Pakuan can actively inform service interruptions that may arise due to work to be performed. 


\section{Recommendations}

This research is only limited to identifying complaints that arise and do not satisfy the customer and what communication strategies are carried out by PDAM Tirta Pakuan. This research has not identified the obstacles that might arise in implementing the communication strategy. Therefore further research is needed that also identifies these obstacles. New research can also be carried out by applying Image Restoration Theory, which will further support this research in handling complaints, opinions, or problems arising from the community so that it can trigger a crisis and threaten the image or reputation of PDAM Tirta Pakuan.

\section{REFERENCES}

Bell SJ, Luddington JA. 2006. Coping with customer complaints. Journal of Service Research. Sage Publications 8(3). doi:10.1177/1094670505283 $785 \mathrm{er}$.

Brewer B. 2007. Citizen or customer? Complaints handling in the public sector. International Review of Administrative Sciences 73(4):549-556. https://doi.org/10.1177/0020852307083457.

Cho Y, Im I, Hiltz R. 2003. The impact of e-services failures and customer complaints on electronic commerce customer relationship management. Journalof ConsumerSatisfaction, Dissatisfaction and Complaining Behavior 16: 106-118.

Crosby LA, Stephens N. 1987. Effect of relationship marketing on satisfaction, retention and prices in the life insurance industry. Journal of Marketing Research 24(4). https://doi. org/10.1177/002224378702400408.

Cuttlip SM, Center AH, Broom GM. 2009. Effective Public Relations. Jakarta: Prenada Media.

Daryanto, Setiabudi I. 2014. Konsumen dan Pelayanan Prima. Yogyakarta: Gava Media.

Davidow M.2003. Organizational responses to customer complaints: what works and what doesn't. Journal of Service Research 5(3): 225-250. https://doi.org/10.1177/1094670502238917.

Dinnen R, Hassanien A. 2011. Handling customer oomplaints in the hospitality industry. International Journal of Customer Relationship Marketing and Management (IJCRMM) 2(1):23. https://doi.org/10.4018/jcrmm.2011010105.
Fanny O, Muslim, Siregar MRA. 2020. Hubungan kualitas pelayanan keluhan dengan kepuasan pelanggan. Jurnal Penelitian Sosial Ilmu Komunikasi Universitas Pakuan 2(1):1-15.

Fierro JC, Melero I, Sese FJ. 2015. Managing complaints to improve customer profitability. Journal of Retailing 91(1): 109-124. doi./10.1016/j. jretai.2014.09.004.

Gunarathne P, Rui H, Seidmann A. 2017. Whose and what social media complaints have happier resolutions? evidence from twitter. Journal of Management Informations Systems 34(2): 314340. https://doi.org/10.1080/07421222.2017.13 34465.

Hasugian H, Idrus M. 2015. Rancang bangun sistem informasi penanganan keluhan pelanggan pada PT jasko prima sejahtera. Jurnal SENTIKA (Seminar Nasional Teknologi Informasi) 143150.

Herlina S. 2015. Strategi komunikasi humas dalam membentuk citra pemerintahan di kota malang. Jurnal Ilmu Sosial dan Ilmu Politik 4(3):49500.

Indriyani S, Mardiyana S. 2016. Pengaruh penanganan keluhan (complaint handling) terhadap kepercayaan dan komitmen Mahasiswa pada Perguruan Tinggi Swasta di Bandar Lampung. Jurnal Bisnis Darmajaya 2(1): 1-13.

Pardede FA. 2016. Strategi komunikasi PT agung automall pangkalan kerinci dalam menangani keluhan pelanggan. JOM FISIP 3(2):1-15.

Pemerintah Indonesia. 2009. Undang-Undang Nomor 25 Tahun 2009 tentang Pelayanan Publik. Lembaran Negara RI Tahun 2009 Nomor 112. Jakarta: Sekretariat Negara.

[Pemkot Bogor] Pemerintah Kota Bogor. 2018. Peraturan Walkota Bogor No. 54 Tahun 2018 tentang Perubahan atas Peraturan Walikota Bogor Nomor 14 Tahun 2018 tentang Struktur Organisasi dan Tata Kerja Perusahaan Daerah Air Minum (PDAM) Tirta Pakuan Kota Bogor. Berita Daerah Kota Bogor Nomor 54 Tahun 2018 Seri E Nomor 36. Bogor: Sekretariat Daerah Kota Bogor.

Pratama ID. 2017. Bahasa komplain di media sosial Twitter.JurnalBahasaSastradan Pengajarannya 1(1): 35-56.

SupriyantoW.2019. StrategikomunikasiinternalPDAM Tirta Satria mengatasi keluhan pelanggan. Warta ISKI (Ikatan Sarjana Komunikasi Indonesia) 
2(1):48-53.

Tajibu K. 2013. Metode Penelitian Komunikasi. Makassar: Alauddin University Press.

Tjiptono F. 2005. Pemasaran Jasa. Malang: Bayumedia Publishing.
Yuliarmi NN, Riyasa P. 2007. Analisis faktor-faktor yang mempengaruhi kepuasan pelanggan terhadap pelayanan PDAM Kota Denpasar. Buletin Studi Ekonomi Fakultas Ekonomi Universitas Udayana Denpasar 12(1):9-28. 